\title{
Collagen metabolism in adjuvant-induced arthritis in the rat
}

\author{
Z. TRNAVSKÁ, J. GRIMOVÁ, AND K. TRNAVSKÝ \\ From the Research Institute of Rheumatic Diseases, Piešt'any, and the Research Institute for Pharmacy \\ and Biochemistry, Prague, Czechoslovakia
}

The adjuvant arthritis of the rat is a systemic disease afflicting the musculoskeletal structures, accompanied by a number of visceral manifestations (Pearson, 1956; Pearson and Wood, 1959). It has been receiving considerable attention in studies of the factors that may influence the development and course of the rheumatic diseases in man (Leader, Gorham, and Wagner, 1967). This experimental arthritis often serves for testing the efficacy of anti-inflammatory and immunosuppressive agents (Currey and Ziff, 1966; Ward and Cloud, 1966; Winter and Nuss, 1966; Rosenthale and Nagra, 1967; Winder, Lembke, and Stephens, 1969). Our present knowledge of the pathogenesis of the adjuvant arthritis indicates that this experimental disease is a generalized immunological cell-mediated response to an antigen present in mycobacteria.

The systemic character of the disease and its common features with human disease instigated our studies of the metabolic turnover of collagen in rats with adjuvant arthritis. We were interested in learning the reactions shown by this essential protein component of connective tissue during various phases of the arthritic process. Up to the present, only the metabolic turnover of the matrix mucopolysaccharides occurring directly within the inflammatory focus located in the rat limb, has been described (Gietka, 1969).

\section{Material and methods}

Our experiments were carried out on male Wistar rats, initially weighing $80 \mathrm{~g}$. each. The experimental group received $0.1 \mathrm{ml}$. Freund's adjuvant per animal, injected intradermally into the dorsum of the tail root. The adjuvant contained $10 \mathrm{mg}$. heat-killed Mycobacterium tuberculosis, $\mathrm{H}_{37} \mathrm{R}_{\mathrm{v}}$ strain, per millilitre sterile paraffin oil. Both the experimental and control animals received a standard diet; starting $12 \mathrm{hrs}$ before and continuing during the urine collection in metabolic cages, the animals received only water. The whole experiment was divided into three parts, as follows:

(1) A subgroup of the controls and a subgroup of the experimental animals with adjuvant arthritis received, on

Accepted for publication November 19, 1971. the 25th day after the injection of Freund's adjuvant, $15 \mu \mathrm{Ci}$ of ${ }^{14} \mathrm{C}$-proline per $100 \mathrm{~g}$. body weight (uniformly $\omega^{\omega}$ labelled ${ }^{14} \mathrm{C}$-proline, specific radio activity $\left.98 \cdot 1 \mu \mathrm{Ci} / \mathrm{mMol}\right)$. (2) Other subgroups of the controls and of the arthritic $\omega_{-\omega}^{\omega}$ animals received the same doses of labelled proline on the ${ }_{\circ}^{+}$ 46th day after the injection of the Freund's adjuvant. $\frac{}{3}$ In both these experiments urine was collected after $12 \mathrm{hrs}$, and 24-hr urine collections were then obtained $\overleftarrow{\subseteq}$ between the 4th and 5th days after the administration of the labelled proline. At the same intervals, viz. 12 and $120 \vec{\omega}$ hrs after proline injection, the animals were killed and $N$ their skins were removed. The skin was shaved, liberated from subcutaneous fat, homogenized, and extracted with $0.45 \mathrm{M}$ solution of sodium chloride $(\mathrm{pH} 7.4)$ at $5^{\circ} \mathrm{C}$. for $24 \mathrm{hrs}$. After centrifugation at $25,000 \mathrm{G}$. the ex-⿳亠二口犬 traction was twice repeated. The combined supernatants containing neutral salt soluble collagen (NSC) were $\mathbb{Q}$ dialysed against running water for $48 \mathrm{hrs}$. The fibrils thus obtained were briefly centrifuged and then hydrolysed with $6 \mathrm{~N} \mathrm{HCl}$ for $20 \mathrm{hrs}$ at $105^{\circ} \mathrm{C}$. The residue of the homogenate, consisting of insoluble collagen (ISC), was likewise hydrolysed. In all hydrolysates of both the NSC and ISC, the hydroxyproline contents were determined by the method of Stegemann (1958), and the radioactivity of ${ }^{14} \mathrm{C}$-hydroxyproline was determined by the method of Juva and Prockop (1966) modified by Nordwig, Kobrle, and Pfab (1967). Urine samples were likewise hydrolysed; $\delta$ the hydroxyproline contents were determined by the method of Prockop and Udenfriend (1960), and the radio-o activity of ${ }^{14} \mathrm{C}$-hydroxyproline by the modified method of Juva and Prockop (1966). The radioactivity was? measured with a scintillation counter Mark I (Nuclear Chicago). The counting efficiency of the liquid N scintillation counter was 80 per cent.

(3) The remaining subgroups of animals with adjuvant $N$ arthritis and controls received $25 \mu \mathrm{Ci}$ of ${ }^{14} \mathrm{C}$-proline per ${ }^{\omega}$ $100 \mathrm{~g}$. body weight intraperitoneally on the 32nd day after the administration of Freund's adjuvant. At intervals 6 of 25,28 , and 30 days after the injection of the labelled $\Phi$ proline, 24-hr urine was collected from these animals? and processed as described above.

\section{Results}

The metabolism of collagen in rats with adjuvant arthritis was investigated in the manner described $\delta$ for extended periods of up to 62 days, after the 
administration of Freund's adjuvant. In our animals, arthritis began at about 18 days after administration.

Only animals with fully developed polyarthritis were included in the experiment. The growth rate of the animals with adjuvant arthritis being slower than that of the control animals of the same age ('age controls'), we used at each sampling interval an additional control group of animals, in which the individual body weight approximated to that of the arthritic rats ('weight controls'). These weight controls, however, were younger than the former. Because weight controls did not show any substantial difference against age controls, we present only the results with age controls (hereafter termed 'controls'). At each experimental interval, four rats with adjuvant arthritis and four controls were killed and processed.

\section{GROUPS 1 AND 2}

\section{Collagen synthesis in rats with adjuvant arthritis}

Collagen synthesis was checked by determining both the specific and total radioactivities of ${ }^{14} \mathrm{C}$-hydroxyproline of the neutral salt soluble collagen (NSC), at intervals of 12 and $120 \mathrm{hrs}$ after the administration of ${ }^{14} \mathrm{C}$-proline, on the 25 th or 46 th day, respectively, after the injection of Freund's adjuvant. In neither experiment were differences found between the contents of the soluble collagen in the experimental groups and in the age controls (Table I). In both experiments, the specific and total radioactivities of ${ }^{14} \mathrm{C}$-hydroxyproline in the animals with adjuvant arthritis were lower than in the control group.

\section{Catabolism of soluble collagen in rats with adjuvant} arthritis

A possible explanation of the decreased specific and total radioactivities of NSC in arthritic rats was obtained by determining the urinary excretion of ${ }^{14} \mathrm{C}$-hydroxyproline during the first $12 \mathrm{hrs}$ after the injection of ${ }^{14} \mathrm{C}$-proline (Table II). In this period the excretion of hydroxyproline indicates the catabolism of soluble collagen. In both groups, the animals with adjuvant arthritis always excreted more hydroxyproline (160 to 170 per cent. of that excreted by the control group).

The specific radioactivity of urinary ${ }^{14} \mathrm{C}$-hydroxyproline in the arthritic rats was lower than that in the controls. This may have been due to dilution, because the arthritic rats excreted much more hydroxyproline. In both experiments, however, the total radioactivity of urinary ${ }^{14} \mathrm{C}$-hydroxyproline in the arthritic rats was raised, especially in the second experiment (46 days after the application of Freund's adjuvant).

Conversion of soluble to insoluble collagen in rats with adjuvant arthritis

This was investigated by determining the radioactivity of ${ }^{14} \mathrm{C}$-hydroxyproline in insoluble collagen at intervals of 12 and $120 \mathrm{hrs}$ after the injection of ${ }^{14} \mathrm{C}$-proline. Again, two sets of experiments were performed, the labelled proline being administered on

Table I Yield of neutral salt-soluble collagen and specific and total activity of ${ }^{14} C$-hydroxyproline of neutral salt soluble collagen in controls and in animals with adjuvant-induced arthritis

\begin{tabular}{|c|c|c|c|c|c|}
\hline \multirow{2}{*}{$\begin{array}{l}\text { Days } \\
\text { after } \\
\text { injection } \\
\text { of } \\
\text { adjuvant }\end{array}$} & \multirow{2}{*}{$\begin{array}{l}\text { Hours } \\
\text { after } \\
\text { adminis- } \\
\text { tration of } \\
{ }^{14} \mathrm{C}- \\
\text { proline }\end{array}$} & \multirow[t]{2}{*}{ Group } & \multicolumn{3}{|c|}{ Neutral salt soluble collagen (mean and range) } \\
\hline & & & $\begin{array}{l}\text { Content ( } m g . / 100 ~ m g . \\
\text { collagen) }\end{array}$ & 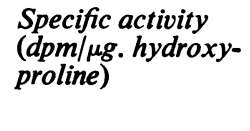 & $\begin{array}{l}\text { Total activity } \\
(\text { dpm/ } / 100 \mathrm{mg} . \\
\text { collagen })\end{array}$ \\
\hline \multirow[t]{2}{*}{25} & 12 & $\begin{array}{l}\mathrm{C} \\
\mathrm{A}\end{array}$ & $\begin{array}{l}2 \cdot 95 \\
2 \cdot 33-3 \cdot 78 \\
2 \cdot 61 \\
2 \cdot 45-3 \cdot 27\end{array}$ & $\begin{array}{l}13 \cdot 69 \\
10 \cdot 44-16.37 \\
11 \cdot 70 \\
10 \cdot 56-13.66\end{array}$ & $\begin{array}{l}5,409 \\
4,912-6,019 \\
4,529 \\
4,312-4,779\end{array}$ \\
\hline & 120 & $\begin{array}{l}\mathbf{C} \\
\mathbf{A}\end{array}$ & $\begin{array}{l}3 \cdot 10 \\
3 \cdot 04-3 \cdot 20 \\
2 \cdot 71 \\
2 \cdot 00-3 \cdot 35\end{array}$ & $\begin{array}{l}1 \cdot 83 \\
1 \cdot 68-2 \cdot 12 \\
1 \cdot 03 \\
0 \cdot 83-1 \cdot 22\end{array}$ & $\begin{array}{l}760 \\
705-864 \\
381 \\
222-522\end{array}$ \\
\hline \multirow[t]{2}{*}{46} & 12 & $\begin{array}{l}\mathrm{C} \\
\mathrm{A}\end{array}$ & $\begin{array}{l}2 \cdot 71 \\
1 \cdot 97-3 \cdot 06 \\
2 \cdot 68 \\
2 \cdot 36-2 \cdot 90\end{array}$ & $\begin{array}{l}16 \cdot 12 \\
7 \cdot 66-20 \cdot 11 \\
10 \cdot 67 \\
8 \cdot 89-12 \cdot 34\end{array}$ & $\begin{array}{l}4,978 \\
3,141-6,638 \\
3,855 \\
2,821-4,498\end{array}$ \\
\hline & 120 & $\begin{array}{l}\mathbf{C} \\
\mathbf{A}\end{array}$ & $\begin{array}{l}3 \cdot 74 \\
3 \cdot 14-4 \cdot 12 \\
3 \cdot 21 \\
3 \cdot 11-3 \cdot 32\end{array}$ & $\begin{array}{l}2 \cdot 96 \\
2 \cdot 34-3 \cdot 69 \\
2 \cdot 17 \\
1 \cdot 83-2 \cdot 89\end{array}$ & $\begin{array}{l}1,496 \\
1,205-2,041 \\
936 \\
764-1,272\end{array}$ \\
\hline
\end{tabular}

$\mathbf{C}=$ control; $\quad \mathbf{A}=$ adjuvant arthritis. 
Table II Urinary excretion of hydroxyproline and specific and total activity of urinary ${ }^{14} C$-hydroxyproline during first 12 hrs after ${ }^{14} \mathrm{C}$-proline administration in controls and in animals with adjuvant-induced arthritis

\begin{tabular}{|c|c|c|c|c|}
\hline \multirow{2}{*}{$\begin{array}{l}\text { Days after } \\
\text { injection } \\
\text { of } \\
\text { adjuvant }\end{array}$} & \multirow[t]{2}{*}{ Group } & \multicolumn{3}{|c|}{ Urinary hydroxyproline (mean and range) } \\
\hline & & $\begin{array}{l}\text { Excretion } \\
(\mu g . / 12 \text { hrs })\end{array}$ & $\begin{array}{l}\text { Specific activity } \\
\text { (dpm/ug. hydroxy- } \\
\text { proline })\end{array}$ & $\begin{array}{l}\text { Total activity } \\
(\text { dpm })\end{array}$ \\
\hline 25 & $\begin{array}{l}\mathrm{C} \\
\mathrm{A}\end{array}$ & $\begin{array}{l}189 \cdot 1 \\
141 \cdot 7-237 \cdot 6 \\
342 \cdot 5 \\
269 \cdot 5-444 \cdot 7\end{array}$ & $\begin{array}{l}16 \cdot 42 \\
14 \cdot 00-20 \cdot 53 \\
10 \cdot 87 \\
8 \cdot 82-12.60\end{array}$ & $\begin{array}{l}3,148 \\
2,906-3,323 \\
3,935 \\
3,921-3,949\end{array}$ \\
\hline 46 & $\begin{array}{l}\mathrm{C} \\
\mathrm{A}\end{array}$ & $\begin{array}{l}239 \cdot 5 \\
192 \cdot 3-289 \cdot 1 \\
413 \cdot 1 \\
321 \cdot 5-516 \cdot 0\end{array}$ & $\begin{array}{l}14 \cdot 42 \\
10 \cdot 74-25 \cdot 71 \\
13 \cdot 67 \\
11 \cdot 35-17 \cdot 00\end{array}$ & $\begin{array}{l}3,481 \\
2,672-5,779 \\
5,484 \\
4,475-6,030\end{array}$ \\
\hline
\end{tabular}

$\mathbf{C}=$ control; $\mathbf{A}=$ adjuvant arthritis.

Table III Yield of insoluble collagen and specific and total activity of ${ }^{14} \mathrm{C}$-hydroxyproline of insoluble collagen in controls and animals with adjuvant-induced arthritis

\begin{tabular}{|c|c|c|c|c|c|}
\hline \multirow{2}{*}{$\begin{array}{l}\text { Days } \\
\text { after } \\
\text { injection } \\
\text { of } \\
\text { adjuvant }\end{array}$} & \multirow{2}{*}{$\begin{array}{l}\text { Hours } \\
\text { after } \\
\text { administra- } \\
\text { tion of } \\
{ }^{14} \mathrm{C}- \\
\text { proline }\end{array}$} & \multirow[t]{2}{*}{ Group } & \multicolumn{3}{|c|}{ Insoluble collagen (mean and range) } \\
\hline & & & $\begin{array}{l}\text { Content } \\
\text { (mg./100 mg. } \\
\text { collagen) }\end{array}$ & $\begin{array}{l}\text { Specific activity } \\
\text { (dpm/ng. } \\
\text { hydroxyproline) }\end{array}$ & $\begin{array}{l}\text { Total activity } \\
\text { (dpm/100 mg. } \\
\text { collagen })\end{array}$ \\
\hline \multirow[t]{2}{*}{25} & 12 & $\begin{array}{l}\mathrm{C} \\
\mathrm{A}\end{array}$ & $\begin{array}{l}97 \cdot 22 \\
96 \cdot 18-97 \cdot 87 \\
97 \cdot 15 \\
95 \cdot 85-97 \cdot 51\end{array}$ & $\begin{array}{l}0.11 \\
0.06-0.14 \\
0.08 \\
0.07-0.09\end{array}$ & $\begin{array}{l}1,434 \\
835-1,883 \\
1,111 \\
987-1,275\end{array}$ \\
\hline & 120 & $\begin{array}{l}\mathrm{C} \\
\mathrm{A}\end{array}$ & $\begin{array}{l}96 \cdot 86 \\
96 \cdot 83-96 \cdot 92 \\
97 \cdot 26 \\
96 \cdot 61-97 \cdot 96\end{array}$ & $\begin{array}{l}0.35 \\
0.24-0.41 \\
0.16 \\
0.11-0.21\end{array}$ & $\begin{array}{l}4,586 \\
3,130-5,382 \\
2,063 \\
1,435-2,713\end{array}$ \\
\hline \multirow[t]{2}{*}{$\overline{46}$} & 12 & $\begin{array}{l}\mathrm{C} \\
\mathrm{A}\end{array}$ & $\begin{array}{l}97 \cdot 35 \\
96 \cdot 62-97 \cdot 99 \\
97 \cdot 31 \\
97 \cdot 15-97 \cdot 60\end{array}$ & $\begin{array}{l}0.11 \\
0.08-0.13 \\
0.05 \\
0.04-0.06\end{array}$ & $\begin{array}{l}1,475 \\
1,040-1,783 \\
660 \\
541-773\end{array}$ \\
\hline & 120 & $\begin{array}{l}\mathrm{C} \\
\mathrm{A}\end{array}$ & $\begin{array}{l}96 \cdot 22 \\
95 \cdot 84-96 \cdot 82 \\
96 \cdot 75 \\
96 \cdot 64-96 \cdot 85\end{array}$ & $\begin{array}{l}0.36 \\
0 \cdot 32-0.41 \\
0.16 \\
0 \cdot 11-0.18\end{array}$ & $\begin{array}{l}4,700 \\
4,137-5,270 \\
2,041 \\
1,451-2,416\end{array}$ \\
\hline
\end{tabular}

the 25 th and 46th day of the arthritic process. In neither experiment was any difference found in the total mass of insoluble skin collagen between the arthritic and control groups (Table III). Both the specific and the total radioactivities of ${ }^{14} \mathrm{C}$-hydroxyproline in the insoluble collagen were always lower in the arthritic animals than in the control group. This difference was particularly conspicuous in the second experiment (labelled proline administered on the 46th day of the arthritic process).

If the total radioactivity of insoluble and soluble collagen is expressed as a percentage of the sum of both, $12 \mathrm{hrs}$ after the administration of the labelled proline, 86 per cent. of the registered radioactivity was present in the soluble collagen, and 14 per cent. in the insoluble collagen in the arthritic group.
The percentages in the control group were 77 and 23 per cent. respectively.

After $120 \mathrm{hrs}$ the differences were still more marked: in the arthritic rats, 32 per cent. of the radioactivity was contained in the soluble, and 68 per cent. in the insoluble collagen, whereas the controls showed 24 per cent. in the soluble and 76 per cent. in the insoluble collagen. These findings indicate that the conversion of soluble to insoluble collagen is retarded in animals with adjuvant arthritis.

GROUP 3

Catabolism of insoluble collagen in rats with adjuvant arthritis

In the third part of the experiment, the animals each received $25 \mu \mathrm{Ci}{ }^{14} \mathrm{C}$-proline on the $32 \mathrm{nd}$ day after the 
injection of Freund's adjuvant. 24-hr urine was collected on the 25 th, 28 th, and 30 th days after the administration of the radioactive proline. There was no substantial difference in the amounts of hydroxyproline excreted by the individual experimental groups (Table IV). Both groups also exhibited similar values of specific radioactivity, the total radioactivity of urinary ${ }^{14} \mathrm{C}$-hydroxyproline being slightly lower on average in the arthritic rats.

The conclusion may be drawn that no catabolism of the insoluble collagen took place in the rats with adjuvant arthritis.

\section{Discussion}

The isotope technique makes it possible to assess the radioactivity of ${ }^{14} \mathrm{C}$-hydroxyproline produced by administration of ${ }^{14} \mathrm{C}$-proline in individual fractions of skin collagen, as well as its urinary excretion. The total metabolic turnover of collagen, its synthesis, the conversion rate of soluble to insoluble collagen, and the catabolism of both the soluble and the insoluble fractions, may be measured. Collagen synthesis can be estimated by determining the radioactivity of ${ }^{14} \mathrm{C}$-hydroxyproline in soluble collagen within the first hours and days after the injection of ${ }^{14} \mathrm{C}$-proline. The measurement of radioactivity of ${ }^{14} \mathrm{C}$-hydroxyproline in soluble and in insoluble collagen yields information about the conversion of the younger soluble forms of collagen to the mature insoluble forms. The radioactivity of urinary ${ }^{14} \mathrm{C}$ hydroxyproline, determined $12 \mathrm{hrs}$ after the administration of ${ }^{14} \mathrm{C}$-proline, is an indicator of the catabolism of the soluble collagen synthesized de novo. The catabolism of mature insoluble collagen is reflected in the radioactivity of urinary ${ }^{14} \mathrm{C}$ hydroxyproline excreted 4 wks and more after the administration of ${ }^{14} \mathrm{C}$-proline (Prockopand Kivirikko, 1968).

Table IV Urinary excretion of hydroxyproline and specific and total activity of urinary ${ }^{14} C$-hydroxyproline in controls and animals with adjuvant-induced arthritis

\begin{tabular}{|c|c|c|c|c|c|}
\hline \multirow{2}{*}{$\begin{array}{l}\text { Days } \\
\text { after } \\
\text { injection } \\
\text { of } \\
\text { adjuvant }\end{array}$} & \multirow{2}{*}{$\begin{array}{l}\text { Days } \\
\text { after } \\
{ }^{14} \mathrm{C}- \\
\text { proline }\end{array}$} & \multirow[t]{2}{*}{ Group } & \multicolumn{3}{|c|}{ Urinary hydroxyproline (mean and range) } \\
\hline & & & $\begin{array}{l}\text { Excretion } \\
\text { ( } \mu \mathrm{g} . / 24 \mathrm{hrs})\end{array}$ & 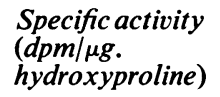 & $\begin{array}{l}\text { Total activity } \\
(\text { dpm })\end{array}$ \\
\hline 57 & $\begin{array}{l}25 \\
(24 \mathrm{hrs})\end{array}$ & $\begin{array}{l}\mathrm{C} \\
\mathrm{A}\end{array}$ & $\begin{array}{l}339 \cdot 5 \\
265 \cdot 3-397 \cdot 3 \\
337 \cdot 4 \\
261 \cdot 1-499 \cdot 5\end{array}$ & $\begin{array}{l}0.44 \\
0.27-0.68 \\
0.57 \\
0.45-0.67\end{array}$ & $\begin{array}{l}151 \cdot 5 \\
98 \cdot 5-218 \cdot 3 \\
193 \cdot 6 \\
120 \cdot 0-296 \cdot 3\end{array}$ \\
\hline 60 & $\begin{array}{l}28 \\
(24 \mathrm{hrs})\end{array}$ & $\begin{array}{l}\mathrm{C} \\
\mathrm{A}\end{array}$ & $\begin{array}{l}326 \cdot 9 \\
287 \cdot 8-357 \cdot 5 \\
371 \cdot 6 \\
200 \cdot 0-557 \cdot 8\end{array}$ & $\begin{array}{l}0 \cdot 81 \\
0 \cdot 43-1 \cdot 18 \\
0 \cdot 61 \\
0 \cdot 14-0.98\end{array}$ & $\begin{array}{l}258 \cdot 0 \\
135 \cdot 3-340 \cdot 6 \\
199 \cdot 9 \\
76 \cdot 5-390 \cdot 1\end{array}$ \\
\hline 62 & $\begin{array}{l}30 \\
(24 \mathrm{hrs})\end{array}$ & $\begin{array}{l}\mathrm{C} \\
\mathrm{A}\end{array}$ & $\begin{array}{l}420 \cdot 2 \\
381 \cdot 3-502 \cdot 9 \\
306 \cdot 8 \\
296 \cdot 1-326 \cdot 5\end{array}$ & $\begin{array}{l}0.63 \\
0.52-0.69 \\
0.46 \\
0.36-0.51\end{array}$ & $\begin{array}{l}263 \cdot 1 \\
251 \cdot 5-275 \cdot 5 \\
139 \cdot 2 \\
117 \cdot 4-154 \cdot 2\end{array}$ \\
\hline
\end{tabular}

The development of adjuvant arthritis is accompanied by marked changes in the metabolic turnover of collagen. A local articular inflammatory process is likely to form part of the changes in collagen metabolism. To a great extent these changes reflect a systemic reaction of the whole organism. The development of the adjuvant arthritis is a dynamic process, advancing from an acute to a chronic phase. In the acute phase, on the 25 th day after the injection interacts only with the catabolism of soluble collagen in the organism. Collagen synthesized de novo is subject to augmented degradation. On the 46th day after the administration of Freund's adjuvant, when the adjuvant-induced disease has already reached the chronic phase, still more marked changes occur. The degradation of the new collagen is further intensified, and the conversion rate of soluble to insoluble collagen diminishes. In our experiments adjuvant arthritis was not accompanied by increased degradation of insoluble collagen. The chief consequence of adjuvant arthritis is increased degradation of the younger forms of collagen and retarded conversion of the younger forms into the mature insoluble forms.

The articular changes in adjuvant-induced arthritis are accompanied by an increase in the activity of the lysosomal enzymes, beta glucuronidase, alkaline phosphatase, and collagenolytic enzyme (Anderson, 1970). The activity of the last-named enzyme begins to increase between the 25th and the 40th day after the administration of Freund's adjuvant, as does the serum proteolytic activity, casein serving as substrate (Pelczarska, Giełdanowski, and Halawa, 1969). It is probable that a release of collagenolytic enzymes may play a role in the catabolism of the collagen synthesized de novo, which is less stable and therefore more susceptible to enzymic degradation. of Freund's adjuvant, the adjuvant-induced disease 
The inhibition of the conversion of soluble to insoluble collagen may be another unfavourable factor, because of the consequent retardation of the formation of more stable forms of collagen which are more resistant to pathogenic influences. The changes in the metabolism of collagen are a manifestation of the systemic damage produced by adjuvant arthritis.

\section{Summary}

In rats with adjuvant-induced arthritis, the meta- bolism of collagen was investigated after an injection of ${ }^{14} \mathrm{C}$-proline, both the specific and total radioactivity of ${ }^{14} \mathrm{C}$-hydroxyproline being determined in skin collagen fractions and in urine. It was found that the catabolism of the collagen synthesized de novo is intensified in the acute phase of the arthritis, whereas in the chronic phase the catabolic change is accompanied by a retardation in the conversion of soluble to insoluble collagen. Changes in collagen metabolism reflect a mainly systemic reaction to the administration of Freund's adjuvant.

\section{References}

Anderson, A. J. (1970) Ann. rheum. Dis., 29, 307 (Lysosomal enzyme activity in rats with adjuvant-induced arthritis)

CURReY, H. L. F., and ZIFF, M. (1966) Lancet, 2, 889 (Suppression of experimentally induced polyarthritis in the rat by heterologous anti-lymphocyte serum)

GIETKA, J. (1969) Abstract XII. Congressus Rheumatologicus Internationalis, Prague, Abstract No. 729 (Studies on the metabolism of connective tissue mucopolysaccharides in adjuvant-induced polyarthritis in rats)

Juva, K., and Prockop, D. J. (1966) Analyt. Biochem., 15, 77 (Modified procedure for the assay of $\mathbf{H}^{3}$ - or $\mathrm{C}^{14}$ labeled hydroxyproline)

LEADER, R. W., GoRHAM, J. R., and WAGNer, B. M. (1967) In 'The Connective Tissue,' ed. B. M. Wagner, p. 95. Williams and Wilkins, Baltimore (Connective tissue diseases of animals other than man)

Nordwig, A., Kobrle, V., and PfaB, F. K. (1967) Biochem. biophys. Acta, 147, 487 (Investigations on collagen proline hydroxylation in a cell-free system)

Pearson, C. M. (1956) Proc. Soc. exp. Biol. (N.Y.), 91, 95 (Development of arthritis, periarthritis, and periostitis in rats given adjuvants) and Wood, F. D. (1959). Arthr. and Rheum., 2, 440 (Studies of polyarthritis and other lesions induced in rats by injection of mycobacterial adjuvant. I. General clinical and pathologic characteristics and some modifying factors)

Pelczarska, A., Gieldanowski, J., ANd Halawa, B. (1969) Arch. Immunol. Ther. exp. (Warz.), 17, 597 (Studies on proteolytic activity of blood and the lymphonodal blastic reaction in the course of adjuvant arthritis in rats)

Prockop, D. J., AND KIvIRIKKo, K. I. (1968) In 'Treatise on Collagen', vol. 2, 'Biology of Collagen', part A, p. 215, ed. B. S. Gould. Academic Press, London and New York (Hydroxyproline and the metabolism of collagen)

- AND UDENFRIEND, S. (1960) Analyt. Biochem. 1, 228 (A specific method for the analysis of hydroxyproline in tissues and urine)

Rosenthale, M. E., AND Nagra, C. L. (1967) Proc. Soc. exp. Biol. (N.Y.), 125, 149 (Comparative effects of some immunosuppressive and anti-inflammatory drugs on allergic encephalomyelitis and adjuvant arthritis)

StegemanN, H. (1958) Hoppe-Seyler's Z. physiol. Chem., 311, 41 (Mikrobestimmung von Hydroxyprolin mit Chloramin $\mathrm{T}$ und $p$-Dimethylaminobenzaldehyde)

WARD, J. R., AND CLOUd, R. S. (1966) J. Pharm. exp. Ther., 152, 116 (Comparative effects of anti-rheumatic drugs on adjuvant-induced polyarthritis in rats)

WiNTER, C. A., AND Nuss, G. W. (1966) Arthr. and Rheum., 9, 394 (Treatment of adjuvant arthritis in rats with antiinflammatory drugs)

Winder, C. V., LembKe, L. A., AND Stephens, M. D. (1969) Arthr. and Rheum., 12, 472 (Comparative bio assay of drugs in adjuvant-induced arthritis in rats: Flufenamic acid, mefenamic acid and phenylbutazone) 